Available online at JECE (Journal of Early Childhood Education)

Website: http://journal.uinjkt.ac.id/index.php/jece

Permalink/DOI: http://dx.doi.org/10.15408/jece.v2i2.17530

JECE, 2 (2), Desember 2020, 113-124

\title{
KAK AWAM'S STORYTELLING STRATEGY IN DELIVERING MORAL VALUES FOR CHILDREN
}

\author{
Miratul Hayatiㄹ, Masroro Diah Wahyu Lestari ${ }^{2}$, Nila Nurmawahda ${ }^{3}$ \\ 1,3Universitas Islam Negeri Syarif Hidayatullah Jakarta; \\ 2Universitas Muhammadiyah Jakarta \\ Corresponding e-mail: miratul.hayati@uinjkt.ac.id
}

\begin{abstract}
Storytelling is an exciting learning method that teachers can practice in learning activities. This study investigates the Kak Awam strategies in conducting storytelling to develop moral values in preschool children. This research uses descriptive qualitative. Data were collected by interview, observation, document analysis and video recording. The collected data were analyzed using Miles Huberman analysis, consisting of several stages: data collection, data reduction, data presentation and verification or conclusion. This study explains the storytelling strategies conducted by Kak Awam in delivering moral values can be implemented in learning activities at school.
\end{abstract}

Keywords : story telling strategy, moral values, kak awam

\begin{abstract}
Abstrak
Mendongeng merupakan salah-satu metode pembelajaran yang menarik yang bisa digunakan guru dalam kegiatan pembelajaran. Penelitian ini bertujuan untuk menyelidiki penggunaan strategi mendongeng kak Awam dalam menanamkan nilai-nilai moral pada anak-anak prasekolah. Metode penelitian ini menggunakan deskriptif kualitatif. Data dikumpulkan dengan wawancara, observasi, analisis dokumen dan video rekaman. Data yang terkumpul dianalisis menggunakan analisis Miles Huberman yang terdiri dari beberapa tahapa: pengumpulan data, reduksi data, penyajian data dan verifikasi atau kesimpulan. Hasil penelitian ini memberikan penjelasan tentang strategi mendongeng yang dilakukan oleh kak Awam dalam penyampaian pesan moral yang bisa diimplementasikan dalam kegiatan pembelajaran di sekolah.
\end{abstract}

Keywords : strategi dongeng, pesan moral, kak awam 


\section{Introduction}

Early childhood education is the first learning experience in the school environment for a child. A meaningful learning experience will encourage children to master various skills, foster self-confidence, and introduce a positive attitude. These skills are essential in preparing children for formal schooling and lifelong learning (Thambu, 2017). Therefore, preschool education is a fundamental education that is very important for developing a person's thinking, character, personality, morality, and behavior.

According to Dewey (Cahan, 1994), creating a favorable learning environment must be designed by a teacher. Thus, various approaches, strategies, and techniques need to be utilized to provide holistic education to children. Storytelling is a method that can be used as an educational instrument to teach moral and ethical values to preschool children.

Storytelling as an approach to developing and growing moral consciousness among children is slowly dying out in the modern education system (Tappan \& Brown, 1989). However, storytelling is an effective way to transform moral experiences into moral knowledge. Through storytelling, children create moral preferences when the stories produce real moral experiences. Storytelling has a powerful effect on a child's moral development (Brown, Tappan, Gilligan, Miller, \& Arcyi, 1994).Promoting moral and ethical values is the best way to foster them since childhood. According to Piaget, children aged 2 to 8 years begin to build concepts and identities from the behavior of animated characters and stories. Thus, storytelling has excellent potential as educational media.

Storytelling helps to internalize moral values gradually (Berkowitz \& Gibbs, 1983; Aliakbari et al., 2014; Hunter \& Eder, 2010; Rahiem, Abdullah, Krauss, et al., 2020; Talwar et al., 2016; Sayer et al., 2018; Hidayati, 2019; Awalunisah, 2019; Hermanto, 2019; Rahiem, Abdullah, \& Rahim, 2020). When children are actively involved in listening to fairy tales, the values of kindness will be internalized. Internalization of moral values occurs in social interaction mediated by books or other media because teachers and friends help children reach the Proximal Zone of Developmental (ZPD). By using stories, teachers can transfer many things; helping children develop expressions to maintain cultural and traditional wisdom, making children excited to learn about art and history (Hamilton \& Peyton-Jones, 2010) helps children develop self-confidence, teaches language skills, fosters an attitude and respect.

Fairy tales can help children understand a culture's wisdom (Nelson, 1980), and moral values (Witherell \& Noddings, 1991). Storytelling is a strategy for meaningful learning that helps students understand multiple perspectives and 
complexities in problem-solving and social relations (Egan \& McEwan, 1995). Storytelling becomes an exciting method that impresses children and makes it easier for listeners to understand moral messages than straightforward advice. Besides, through fairy tales, children feel that they are not being intimidated because early childhood cannot sit for a long time listening to the teacher talk and only explaining lessons.

Fairy tales also provide the interaction and construction of knowledge. Joining fairy tales develops listening and concentration skills, enabling them to understand the story's meaning and relate it to real experiences. Storytelling is suitable for children because it makes learning meaningful and fun.

In the concept that it is inextricably connected with all facets of people's lives, the fairy tale is also extraordinary. Fairy tales have provided children with spiritual nourishment for a human, as they invoke faith in their bravery, courage and feelings of love for the motherland (Tursunmurotovich et al., 2020).

Fairy tales are tools for connecting fantasy and imagination with the real world of children. Storytelling allows children to connect the ideal concept of life presented in the story to become their own life experience (Shavkatovna \& Kizi, 2020), and be an excellent way to promote language skills development (listening, reading, understanding) (Shavkatovna \& Kizi, 2020), as well as being a successful catalyst to promote children's thinking, to become motivation in developing their moral life about the ideals and behaviors presented in the story. Listening to fairy tales in the classroom setting will create a shared social experience. The storytelling triggers an emotional response (Wong et al., 2002) such as laughter, sadness, and joy. It can help build children's self-confidence and promote better social and emotional development and encourage the growth of understanding of racial and ethnic diversity and respect for differences around children.

Many people around the world have practiced storytelling to introduce moral values in children. Stories such as the Ramayana in the Hindu tradition, Nasrudin from the Islamic Sufi tradition have long been used to teach children moral lessons (Winston, 2014). These stories were told to children by adults orally. Children also understand bedtime stories from their parents for entertainment.

The ancient Malay community has created and used stories such as Pak Pandir, Lebai Malang, Si Luncai, Mat Jenin, Bawang Putih Bawang Merah, Sang Kancil, and other stories. The story is a medium of social criticism to shape individuals' character, behavior, norms, and morality concerning the public (Osman, 1999). A study also shows the importance of storytelling as an effective method of developing moral imagination (Nussbaum \& Bettini, 1994). 
There are many storytellers of national reputation in Indonesia with their methods and storytelling styles, including Awam Prakoso (who is better known as Kak Awam), the founder of Kampung Dongeng. Kampung Dongeng developed into 28 places that function as a community for teachers or anyone who wants to learn storytelling skills. The purpose of establishing this Kampung Dongeng is to preserve storytelling culture so that teachers and parents do not have to advise children directly and seem more polite. In 2010 Kak Awam received an award from Seto Mulyadi for their concern in storytelling for children, In 2013 received a MURI (Indonesian Worlds Record Museum) for the most extended storytelling category, and in 2016 as an Inspirational Child Protection figure. Kak Awam also works on social media to deliver moral messages through fairy tales. Some of the tales uploaded on Kak Awam's Youtube Channel show a high public interest, seen from the subscriber who reaches 3,217 followers.

This research focused on the storytelling strategy that is implemented by the Kak Awam to be used by teachers in conveying moral messages, both from the ability to choose the appropriate storytelling, expressions, and voice intonation in conveying, the media and tools used, the time and place that are effective for carrying out storytelling activities as well as moral values that are conveyed during the activity.

The strategies obtained from this study can be applied to Early Childhood Education (ECE) learning in the school environment by ECE teachers. So that storytelling is not just conveying stories and words, but fostering children's morals development. This condition is essential for children's development because the character or moral education in the story can influence and play a role in developing the child's character as an audience (Hermanto, 2019).

\section{Method}

This research was conducted in Kampung Dongeng Kak Awam, which is located in Sawah Lama Ciputat. The method used in this research is descriptive qualitative to present detailed data from written or spoken words from participants. The researcher tries to obtain in-depth information to describe the research results or the phenomena about the Kak Awam storytelling method.

Data collection was carried out through structured and unstructured observations by directly observing the events and occurrences during Kak Awam's storytelling activities in the Kampung Dongeng and other places. While the interview is a tool to obtain information, the unstructured interview applied, so information from the informants can be received flexibly. Researchers developed guidelines for conducting interviews with subjects. 
Table 1. Inteview Guidelines

\begin{tabular}{cl}
\hline No & Interview Questions \\
\hline 1 & Fairy tale according to the age criteria of the child \\
\hline 2 & Tell fairy tales with expressiveness \\
\hline 3 & Storytelling with the help of tools or media \\
\hline 4 & Ethics of storytelling language \\
\hline 5 & Place and time of storytelling activity \\
\hline 7 & Give attention to students who are not focused \\
\hline
\end{tabular}

Researchers also took documents in pictures or photos, videos, and various data to support research data related to Kak Awam storytelling strategies. The data analysis technique used the Miles Huberman model of data analysis with stages, namely; (1) data collection, (2) data reduction, (3) data display (4) conclusion drawing or verification (Huberman \& Miles, 1994).

\section{Results and Discussion}

Based on the research objectives, this discussion examines the storytelling strategy of Kak Awam in delivering moral values to children. Among the strategies taken by Kak Awam are as follows:

\section{Choose a fairy tale according to the age criteria of the child}

Kak Awam understands that storytelling is not just telling a story but also understanding its development and characteristics. He decides to become a friend and guide for children by offering interesting stories. According to him, storytelling will convey moral value to children. Improvement of fairy tales to age criteria is essential, for children aged seven years and under usually prefer animals. So, fable is more suitable for children, especially if the animal characters are personified with human-like behaviour, such as buffalo who like to help, the turtle who got the race. This fable is evidenced by the number of cartoon stories that are mostly dominated by animal characters.

In stories about animals, morals can be explained, such as telling the truth, not being allowed to take other people's property, and loving friends. This example connects in the child's memory and becomes the foundation for the child's character development. For children of early elementary school age, the theme of friendship needs to be given priority, because children begin to have strong relationships with other people, especially with their peers. Fairy tales or stories about friendship are the foundation for character building on how to get along and behave with friends as 
they should. Children need other people or friends in life by socializing and interacting, collected from their friendship. At this age, children can take lessons from stories with various characters.

For preschool children, the number of fairy tales recommended would be short and straightforward. Children of this era may not have a full understanding of the world yet. It is also right that the fairy tales recommended to them are about nature, wildlife, friendship, culture, morality, and many fairy tale illustrations (Tursunmurotovich et al., 2020).

Most of the fairy tales suggested for young children of this age reflect ideals of fairness, honesty, and integrity. The young reader would be inspired by the fairy-tale heroine's admiration for the younger reader. The fairy tale is straightforward, but its sense and content are compelling (Mahmudova, 2020).

\section{Tell fairy tales with expressiveness}

Telling fairy tales must be expressive. If the storyteller tells the story with a flat expression, the child will not be interested in listening to it. In storytelling, there must be changes in intonation, expression, and body language. The intonation must be well-defined; the expression on the appearance must match the story. In telling fairy tales, emotions must also be included so that children can follow the lead and live emotionally too. In telling fairy tales, it is also necessary to pay attention to the distinction of expression, the words of each character in the story, emphasize certain dialogues, express emotional expressions in fairy tales such as anger, pain, sadness, joy, surprise, this is useful for children to get to know and feel the patterns of his emotions. With the intonation, it is required to distinguish the characters in the story.

The storyteller must make a character that is appropriate and pleasant for children to catch. To make a character right in the story's context, the storyteller must master the fairy tale's storyline properly. For example, when telling a story which is running because of fear, the storyteller needs to speed up his voice with a facial expression that explains if he is frightened, as well as when bringing a story which is happy and laughing, the storyteller must be able to express it with laughter and a smile that suits the setting which is told. The storyteller needs to change the tone of the voice to distinguish the characters in the story. Also, the intonation must be enlarged or reduced according to the sense of the story being conducted. Kak Awam revealed that he already has 120 kinds of sounds until now, such as animal and vehicle sounds, parents' voices, and children's voices.

\section{Storytelling with the help of tools or media}

In carrying out storytelling activities, Kak Awam is always supported by tools or media to look attractive, so the child can focus more on listening to the story. Early 


\section{JECE (Journal of Early Childhood Education)}

childhood cognitive development in the range of concrete pre-operational and concrete operational stages. Children need concrete media to form their experiences and knowledge, including the concept of a fairy tale or story. The media that is regularly used by Kak Awam is storybooks.

In selecting the storybooks, Kak Awam tries to select books that contain messages of goodness or morals. The book used is not a long story; the size is quite large and contains exciting illustrations. Besides using books, Kak Awam also uses puppets to represent fairy tale characters, such as animals or pictures, to stimulate children's imaginations. Because of this condition, children were more enthusiastic about listening to the storyline of the fairy tales.

\section{Ethics of storytelling language}

In telling fairy tales, the storyteller should use words and sentences that are easy for children to understand. Kak Awam in conveying moral messages using communication that is easy to follow. The language used by the storyteller or teacher is a means to introduce the character and attitude to the children. The choice of words and language styles used in communication with children can have a psychological effect because children are unique, egocentric, and sensitive (Afrianingsih, 2016). At the age of 2-7 years, children's language development develops rapidly. Children express the language they understand in the pattern of moral behavior. At this stage, the child can communicate what they understand based on what they perceive and hear.

Children describe their world symbolically. In telling fairy tales, the storyteller must also pay attention to the clarity of the words or sentences communicated, let these words explain slowly and clearly so that children can follow the fairy tale's contents. When telling the story, try to use the appropriate tone of voice, clear articulation, and several repetitions. Furthermore, fairy tales must contain positive language as a direction for children to act reasonably and correctly.

The storyteller or teacher's command or content can be understood by the child using the positive word. For example, the words "do not", "may not", and "prohibited" can be replaced with alternative uses of the words "should", "would be better" or "for example" in telling fairy tales. Kak Awam is also sometimes used words that are trending and viral, but the words chosen are positive.

Compelling storytelling should promote exploration and language experimentation (Schwartz, 1987). An objective of storytelling is to build meaning through the use of language. Retelling may be advised in a language development emphasis. The involvement of children in storytelling provides novelty to stimulate 
the child's curiosity and sufficient familiarity to allow a child to perceive relationships and succeed in using communication.

\section{Place and time of storytelling activity}

According to Kak Awam, storytelling can be done in the classroom and can practice outside the classroom. For example, in the school garden, terrace, lobby, under a shady tree, or an open area exposed to the sun. For storytelling time, it is not only before the child goes to bed, but whenever there is an opportunity with the child, by looking at the child's situation and condition. Parents or storytellers can do fairy tales when they have free time, morning, afternoon, or evening.

In storytelling, a storyteller should not tell stories for a long duration. The essential thing in storytelling is not the length of time but the quality of the storytelling. 5-10 minutes duration is sufficient so that children can focus and actively participate in listening to stories.

In telling fairy tales, kak Awam takes about 30-60 minutes, depending on the listener. They selected a short duration so that the child does not get bored listening to it. Children aged 4 years need 5-7 minutes to get the right concentration. Ideally, when storytelling for children, only two characters appear in the fairy tale so that the children are not confused. For ages $4-8$ years, the ideal time to tell storytelling is 1015 minutes, the characters shown can already about 4 characters. For ages 8-12 years, the ideal duration for children's storytelling activities is 25-30 minutes, or it could be more dependent on the storyteller's ability to attract children's interest, and the child remains focused on following it.

\section{Give attention to students who are not focused}

Several steps are used by Kak Awam when the child begins to lose focus in listening and involving in storytelling activities includes; (1) Through the icebreaking activity, ice-breaking intend to build a dynamic storytelling atmosphere so that children become enthusiastic and back to concentrate again. The ice-breaking used by Kak Awam is a simple clapping. Clapping is very easy for children to do; the storyteller can modify the ice-breaking method with applause. This simple method uses to entertain and eliminate children's boredom in activities. (2) Invite children to sing along with the lyrics that have been made. Children learn through play. Play is at the heart of early childhood pedagogy in contemporary times, and it has led to the awareness of the importance of a child-centred curriculum approach (Rousseau, Pestalozzi, and Froebel). (3) Through dramatization, dramatization can be arranged in various styles, for example, telling stories in expressive behaviors, using costumes or the media. Dramatization becomes essential as a catalyst for successful storytelling 
activities in delivering moral messages for children (Rahiem, Abdullah, Krauss, et al., 2020).

\section{Kak Awam's moral message through storytelling}

Appropriate moral messages should choose when telling the stories. Children are in the pre-operational stage; Piaget explains this about children's thinking about moral issues. Piaget concluded that children's thinking about moral issues achieves two stages: the age of 4-7 years the children show heteronomous morality and 7-10 years as the autonomous stage. At the heteronomous stage, the child believes that justice and goodness must exist (immanent justice). The child believes that the person who made mistakes and crime will immediately get punishment as a counterattack for bad deeds. They imagine that goodness and justice cannot separate each other from human control in the children's perspective. The second stage is 7-10 years, which Piaget called the transition period between heteronomous morality and autonomous morality. Age 7-10 years is an intermediate stage between heteronomous morality and autonomous morality. In this stage, children exhibit some of the first stages of moral reasoning characteristics and some of the second stage's characteristics, autonomous morality. Entering the age of 10 (autonomous morality), children realize that rules and punishments are human creation due to consensus or mutual agreement.

Fairy tales teach us that we share a sense of justice and fairness, that bad guys always come to a bad end, that people who work hard will succeed, that cleanliness depends on the health and other value examples. Fairy tales provide alternatives, by contrast. These stories will help kids build their imagination, aspire to get excellent vibes and be useful in life. When a mother tells fairy tales, she is genuinely engaging in detail with the child, filling the space in the child's mind, and expressing love for her child (Rahman, 2017).

For this reason, the selection of fairy tales that contain moral messages should prepare appropriately; the goal is to avoid fairy tales in which some actions can influence children's thinking to do wrong or destructive things. Age 7-10 years is an intermediate stage between heteronomous morality and autonomous morality. In this stage, children exhibit some of the first stage of moral reasoning features and some of the second stage's features, autonomous morality. Entering the age of 10 (autonomous morality), children realize that rules and punishments are human creation due to consensus or mutual agreement.

The story must also have the "N-Ach (Need for Achievement) virus", in this case, the delivery of fairy tales or stories need to include good moral values such as the honesty, love, help each other, and generosity so that they can form children who 


\section{JECE (Journal of Early Childhood Education)}

are has a good character and eliminates or avoids terrible tales in the story (Hendri, 2012).

Before completing the story, Kak Awam makes sure the child understands the moral message in the story, by asking the child to recount what he has said. Among the moral messages conveyed by Kak Awam when delivering tales during the research process are as follows: (1) stating greetings when beginning an activity, attempting to make the greetings answered by all audiences, and inserting ethics when starting something in this session. Give a message to appreciate and pray for people who have prayed for us. (2) saying "bismillah" every time they do good deeds by involving children in their activities. (3) being polite to elders, for example by greeting and respecting parents and teachers or older people, thank people who have helped (4) respect and obey their parents, (5) read prayers every time they carry out activities (6) manner in eating session (7) be confident. To foster children's selfconfidence, Kak Awam always asks children to come to the front of the stage in every storytelling session.

\section{Conclusion}

This study found the storytelling strategy of Kak Awam Prakoso as an Indonesian fairy tale actor in conducting moral messages for children. Based on the selection of fairy tales according to the child's age level, the media used, right and correct language ethics and mastery of situations and conditions when the activity occurs. The study's findings can be used to use effective and attractive storytelling activities for children to convey moral messages.

\section{References}

Afrianingsih, A. (2016). Komunikasi Efektif Sebagai Sarana untuk Meningkatkan Penyerapan Bahasa Lisan Anak Usia Dini. Tarbawi: Jurnal Pendidikan Islam, 13(2).

Aliakbari, M., Alipour, A., \& Shirazi, M. D. (2014). The effect of storytelling on moral intelligence components of preschool female students in Isfahan city. Soc Cogn, 3(2), 33-43.

Awalunisah, S. (2019). The Storytelling Method Based on Local Wisdom on Moral Values of 5-6 Years Old Children. 3rd International Conference on Education Innovation (ICEI 2019).

Berkowitz, M. W., \& Gibbs, J. C. (1983). Measuring the developmental features of moral discussion. Merrill-Palmer Quarterly (1982-), 399-410.

BROWN, L., Tappan, M. B., Gilligan, C., Miller, B., \& Arcyri, D. E. (1994). Reading for Self and Moral Voice: A Method for Interpreting Narratives. Moral Development: Caring Voices and Women's Moral Frames, 6, 161.

Cahan, E. D. (1994). John Dewey and human development.

Egan, K., \& McEwan, H. (1995). Narrative in teaching, learning, and research. Teachers 
College Press.

Hamilton, R., \& Peyton-Jones, J. (2010). Richard Hamilton: modern moral matters. Serpentine Gallery.

Hendri. (2012). Pendidikan Karakter Berbasis Dongeng. PT. Remaja Rosdakarya.

Hermanto, Y. A. L. (2019). Visual Storytelling in Folklore Children Book Illustration. Asian Journal of Research in Education and Social Sciences, 1(1), 62-70.

Hidayati, N. N. (2019). Storytelling: One Package Learning in Improving Language Skill and Implanting Character Education on Children. EDUKASI: Jurnal Pendidikan Islam, 7(2), 53-72.

Huberman, A. M., \& Miles, M. B. (1994). Data management and analysis methods.

Hunter, C., \& Eder, D. (2010). The role of storytelling in understanding children's moral/ethic decision-making. Multicultural Perspectives, 12(4), 223-228.

Mahmudova, D. (2020). The Role and Role of Fairy Tales in Child Rearing. International Journal of Progressive Sciences and Technologies, 18(2), 210-212.

Nelson, S. A. (1980). Factors influencing young children's use of motives and outcomes as moral criteria. Child Development, 823-829.

Nussbaum, J. F., \& Bettini, L. M. (1994). Shared stories of the grandparent-grandchild relationship. The International Journal of Aging and Human Development, 39(1), 6780.

Osman, M. (1999). The Tradition of Storytelling in Malaysia.". Traditional Storytelling Today: An International Sourcebook, 138-141.

Rahiem, M. D. H., Abdullah, N. S. M., Krauss, S. E., \& Rahim, H. (2020). Moral Education through Dramatized Storytelling: Insights and Observations from Indonesia Kindergarten Teachers. International Journal of Learning, Teaching and Educational Research, 19(3), 475-490.

Rahiem, M. D. H., Abdullah, N. S. M., \& Rahim, H. (2020). Stories and Storytelling for Moral Education: Kindergarten Teachers' Best Practices. Journal of Early Childhood Education (JECE), 2(1), 1-20.

Rahman, F. (2017). The revival of local fairy tales for children education. Theory and Practice in Language Studies, 7(5), 336-344.

Sayer, I. M., Kristiawan, M., \& Agustina, M. (2018). Fairy Tale as a Medium for Children's Character Cooperation Building. Al-Ta Lim Journal, 25(2), 108-116.

Schwartz, C. A. (1987). “ Jennie Gerhardt": Fairy Tale as Social Criticism. American Literary Realism, 1870-1910, 19(2), 16-29.

Shavkatovna, S. A., \& Kizi, K. G. A. (2020). The Impact Of Storytelling In The Classroom. The American Journal of Social Science and Education Innovations, 2(08), 341-346.

Talwar, V., Yachison, S., \& Leduc, K. (2016). Promoting honesty: The influence of stories on children's lie-telling behaviours and moral understanding. Infant and Child Development, 25(6), 484-501.

Tappan, M., \& Brown, L. M. (1989). Stories told and lessons learned: Toward a narrative approach to moral development and moral education. Harvard Educational Review, 59(2), 182-206.

Thambu, N. (2017). Storytelling and Story Reading: A Catalyst for Inculcate Moral 
Values and Ethics among Preschoolers. International Journal of Academic Research in Business and Social Sciences, 7(6), 1116-1130. https://doi.org/10.6007/ijarbss/v7-i6/3143

Tursunmurotovich, S. S., Eraliyevich, S. X., \& Shuhratovich, I. U. (2020). Illustration and the Influence of Illustrator on Children's Understanding of Fairy Tales and Works of Art in Books. International Journal of Psychosocial Rehabilitation, 24(05), 3526-3533.

Winston, P. H. (2014). The genesis story understanding and story telling system a 21st century step toward artificial intelligence. Center for Brains, Minds and Machines (CBMM).

Witherell, C., \& Noddings, N. (1991). Stories lives tell: Narrative and dialogue in education.

Wong, B. Y. L., Kuperis, S., Jamieson, D., Keller, L., \& Cull-Hewitt, R. (2002). Effects of guided journal writing on students' story understanding. The Journal of Educational Research, 95(3), 179-191. 